\title{
Palaeoenvironmental history of the São Francisco de Paula region in southern Brazil during the late Quaternary inferred from the Rincão das Cabritas core
}

\author{
Vivian Jeske-Pieruschka and Hermann Behling \\ University of Göttingen, Germany
}

\begin{abstract}
We present new palaeoenvironmental data from a $28 \mathrm{I} \mathrm{cm} \mathrm{long} \mathrm{sediment} \mathrm{core} \mathrm{studied} \mathrm{by} \mathrm{means} \mathrm{of} \mathrm{pollen} \mathrm{and} \mathrm{charcoal} \mathrm{analyses} \mathrm{from} \mathrm{Rincão} \mathrm{das} \mathrm{Cabritas}$ of the São Francisco de Paula area, which lies in the wettest region of southern Brazil at the present time.The high-resolution record, dated with seven AMS dates, spans the last $16700 \mathrm{cal}$. BP. The continuous presence of grassland vegetation (Campos) throughout the glacial period reflects cold and markedly drier climatic conditions than today. Nowadays, remote areas of Campos on the highlands represent remnants of an early and widely expanded vegetation of glacial times that was gradually replaced by forest ecosystems during the late Holocene. Araucaria forest began to develop after 3200 cal. BP, with its expansion over Campos starting at about 2950 cal. BP.This was probably due to the presence of a somewhat wetter climate after about 4600 cal. BP, which supported the initial development of forest ecosystems and allowed Atlantic rainforest to spread from the lower regions upwards to higher elevations. The maximum expansion of Araucaria forest took place during the last 1000 years, when it started to be the prevailing vegetation type. This vegetational change coincides with increased precipitation and continuously wetter climatic conditions since $1050 \mathrm{cal}$. BP. The reconstructed fire history indicates a presence of human-related fires on the highlands from the Late Pleistocene until the mid Holocene. Fire activity was markedly reduced after about 3000 cal. BP when forest expanded continuously under regional wetter climatic conditions.
\end{abstract}

\section{Keywords}

Araucaria forest, Campos, climate dynamics, fire history, pollen analysis, southern Brazil, vegetation history

\section{Introduction}

Today, the highlands of southern Brazil are dominated by a mosaic of subtropical grassland (Campos) and Araucaria forest. Together with the Atlantic rainforest on the coastal mountain slopes, which is a hotspot of biodiversity (e.g. Myers et al., 2000; Tabarelli et al., 2005), these ecosystems belong to the Atlantic Forest Biome (Instituto Brasileiro de Geografia e Estatística (IBGE), 2004). The geographical distribution of Araucaria angustifolia trees is concentrated in the southern Brazilian highlands at altitudes above $500 \mathrm{~m}$, but the species also occurs in smaller areas at higher altitudes in southeast Brazil (Hueck, 1953) (Figure 1b).

The dominance of grassland vegetation under cold and dry conditions during glacial periods until the mid Holocene has been recognized by several studies performed in the highlands of Rio Grande do Sul state during the last decades (e.g. Behling et al., 2001, 2004; Roth and Lorscheitter, 1993). Further north, on the highlands of Santa Catarina and Paraná state (Figure 1a), evidence for Campos vegetation during the same periods is given by Behling (1995, 1997, 1998, 2002). During the last glacial maximum (LGM) until the Lateglacial, small populations of forest taxa were only present in refugia situated in deep valleys or on the coastal slopes where sufficient humidity allowed their survival (e.g. Behling et al., 2004; Leonhardt and Lorscheitter, 2010). The initial development of the Atlantic rainforest on the lowlands and valleys of the highlands of Rio Grande do Sul state at the beginning of the Holocene is documented by Lorscheitter (2003). Its spread in an east-west direction since early Holocene is shown by Leal and Lorscheitter (2007). A similar trend for the initial development of the Atlantic rainforest under wetter climatic conditions at the beginning of the Holocene was recognized for the Serra do Tabuleiro in Santa Catarina state (Jeske-Pieruschka, 2011).The first expansion of Araucaria forest in Rio Grande do Sul began at about 3950 yr BP in Cambará do Sul (Behling et al., 2004) and after 4000 yr BP in the São Francisco de Paula region (Leonhardt and Lorscheitter, 2010). The onset of the Araucaria forest expansion in Santa Catarina occurred at about $3460 \mathrm{yr}$ BP in Serra da Boa Vista and at about $2390 \mathrm{yr}$ BP in Serra do Rio do Rastro (Behling, 1995). In Paraná, located north of Santa Catarina, the initial Araucaria forest expansion is documented after $2000 \mathrm{yr}$ BP in Serra do Araçatuba (Behling, 2007) and at about $2850 \mathrm{yr} \mathrm{BP}$ in Serra dos Campos Gerais (Behling, 1997). For the Rio Grande do Sul, pronounced Araucaria forest expansion was recognized since 1060 yr BP in São Francisco de Paula (Behling et al., 2001)

Received 27 September 2010; revised manuscript accepted 24 May 201 I

\section{Corresponding author:}

Vivian Jeske-Pieruschka, Department of Palynology and Climate Dynamics, Albrecht-von-Haller-Institute for Plant Sciences, University of Göttingen, Untere Karspüle 2, 37073 Göttingen, Germany.

Email:vjeske@uni-goettingen.de 


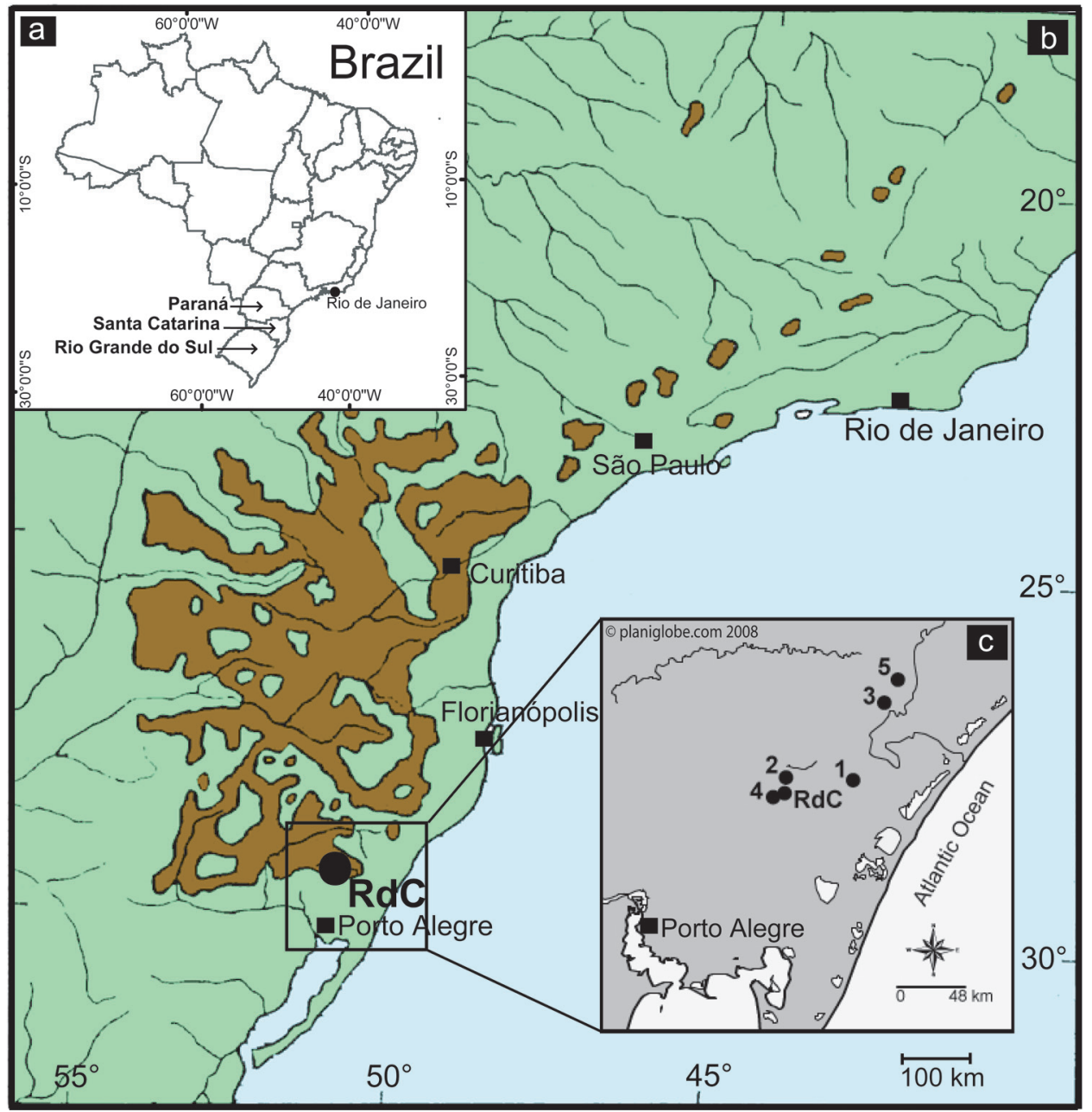

Figure I. (a) The states of southern Brazil, (b) distribution of Araucaria angustifolia in Brazil (after Hueck, 1953), slightly modified and (c) the position of the Rincão das Cabritas $(\mathrm{RdC})$ core together with the other studies performed in the region of São Francisco de Paula and the highlands of Rio Grande do Sul state: I, Aparados da Serra (Roth and Lorscheitter, I 993); 2, Fazenda do Pinto (Behling et al., 200 I); 3, Cambará do Sul (Behling et al., 2004); 4,Alpes de São Francisco (Leonhardt and Lorscheitter, 2010); and 5, São José dos Ausentes (Jeske-Pieruschka et al., 2010)

and after 1140 yr BP for Cambará do Sul (Behling et al., 2004). A marked expansion of Araucaria forest is reported since about 1000 yr BP in Morro da Igreja and Serra do Rio do Rastro, Santa Catarina state (Behling, 1995) and since about 1400 yr BP in Serra dos Campos Gerais, Paraná state (Behling, 1997).

The beginning of the Araucaria forest expansion occurred earlier further south, i.e. in Rio Grande do Sul state (c. $4000 \mathrm{yr}$ BP) than in Santa Catarina (c. 3000 yr BP) and Paraná state (c. 2500 yr BP), both further north. In contrast to this, the marked Araucaria forest expansion occurred later in Rio Grande do Sul and Santa Catarina (last millennia) than further north. Although a climatic change to warmer and wetter conditions arose at the beginning of the Holocene, a long annual dry season may have hampered the initial forest expansion on the southern Brazilian highlands until mid-Holocene times (Behling, 2002). A marked forest expansion over Campos occurred only after about $1100 \mathrm{yr}$ $\mathrm{BP}$ in the southernmost Brazilian highlands. Our question in this context is if the different times of forest expansion were related to regional climatic conditions and/or which other possible factors could have prevented a forest expansion on the highlands. The fact that this studied region has the highest annual precipitation rates of southern Brazil allows the investigation of vegetational changes advantageously. In this work, we present detailed data for the southernmost Brazilian highlands from a temporary high-resolution sedimentary record spanning the last $16700 \mathrm{cal}$. BP.
This represents the best-dated core for the region so far. Therefore, this work provides the best detailed overview of vegetation dynamic, palaeoclimate and fire history of the São Francisco de Paula region. An inter-regional interpretation of environmental changes can be concluded from a comparison of these results.

\section{Environmental setting}

\section{Location}

The studied sedimentary record was collected from a peat bog $\left(29^{\circ} 28^{\prime} 35^{\prime \prime} \mathrm{S}, 50^{\circ} 34^{\prime} 22^{\prime \prime} \mathrm{W}\right)$ situated in the rural property Rincão das Cabritas, approximately $5 \mathrm{~km}$ from the municipality of São Francisco de Paula in the southern Brazilian highlands (Figure 1). The site is located on the eastern plateau of Rio Grande do Sul state, as part of the Serra Geral formation at a distance of c. $500 \mathrm{~m}$ from its escarpment. The Serra Geral corresponds to a geomorphological unit formed by layers of basalt covering Jurassic/Cretaceous sedimentary rocks, the Botucatu formation. It is composed of base-rich basalt in the lower layers and acidic rocks, mostly rhyolite and rhyodacite, in the upper layers (IBGE, 1986). The soil formation is affected by the high precipitation rates under subtropical humid climate. A study in the Pró-Mata area, southern Brazilian highlands (Dümig et al., 2008) describes the occurrence of black-coloured, humus-rich soils in the São Francisco de Paula 
region, which can be classified as Andosols, Umbrisols and Cambisols.

The peat bog, which is surrounded by a forest, is situated in a basin of about $5000 \mathrm{~m}^{2}$ at an altitude of $895 \mathrm{~m}$ a.s.l.

\section{Modern vegetation}

Mosaics of Campos-Araucaria forest characterize the landscape of the highlands in Rio Grande do Sul state. The regional Campos ecosystem is mainly composed of Poaceae, Asteraceae, Fabaceae, Cyperaceae, Apiaceae and Verbenaceae (Boldrini, 2009). Large patches of Araucaria forest cover the region, therewith being the most representative forest formation. This forest type consists of species associated to Araucaria angustifolia, such as Podocarpus lambertii, Drimys brasiliensis, Mimosa scabrella, Ocotea pulchella, O. puberula, Nectandra spp., Ilex paraguariensis, Ilex spp., Matayba elaeagnoides, Cupania vernalis and different species of the Myrtaceae family (Reitz et al., 1988). The slopes of the highlands are covered by Atlantic rainforest from the lower altitudes up to the top of the Serra Geral escarpment. At higher elevations, a gradual transition between these two forest types can be observed. The species-rich Atlantic rainforest is composed of numerous tree species with the predominance of Lauraceae (e.g. Ocotea spp., Nectandra spp.) and Myrtaceae (e.g. Myrcia spp., Myrceugenia spp., Calyptranthes spp., Gomidesia spp.). Other representative taxa are: Alchornea spp., Clethra scabra, Weinmannia spp., Inga spp., Cedrela spp., Cabralea canjerana as well as Mimosaceae (Piptadenia, Parapiptadenia, Anadenanthera). Furthermore, numerous lianas and epiphytes belonging to the plant families of Bromeliaceae, Orchidaceae, Araceae, Cactaceae as well as to the pteridophytes are characteristic for this ecosystem. A more extensive description of the Campos and forests of southern Brazil is published by Lindman (1906). The southern Brazilian vegetation has also been described in Rambo (1951, 1956), Klein (1960, 1975) and Hueck (1966).

The natural vegetation has been influenced anthropogenically since the occupation by the first inhabitants of São Francisco de Paula region, the Caaguaras Indians that lived in the highlands before the European colonization of southern Brazil. However, the Caaguaras Indians were decimated by disease and by the Bandeirantes (Portuguese colonial explorers in Brazil) about AD 1700. At $\mathrm{AD} 1835$ there was already a church but only at $\mathrm{AD} 1878$ the city of São Francisco de Paula was established (www.riogrande.com. $\mathrm{br} /$ municipios/saofranciscodepaula.htm). Currently, land uses such as cattle farming and silvicultural production (extensive Pinus sp. plantations) form a big part of the local economy while other agricultural activities are less represented.

\section{Climate}

The present-day climate on the highlands of Rio Grande do Sul is subtropical humid, with high rainfall distributed throughout the year without a pronounced dry period (Moreno, 1961). It can thus be classified as wet mesothermic climate ( $\mathrm{Cfb}$, Köppen). According to Moreno (1961), São Francisco de Paula has the highest mean annual precipitation (c. $2500 \mathrm{~mm} / \mathrm{yr}$ ) and lowest mean annual temperature $\left(14^{\circ} \mathrm{C}\right)$ of the state, with frequent frosts occurring in winter. The South Atlantic Anticyclone, transporting warm and humid air masses over the continent, dominates the atmospheric circulation over southern Brazil. The Polar Anticyclone with dry and cold air masses also influences the climate of the region, provoking strong rainfall when it clashes with tropical warm and humid air masses (Nimer, 1989). Precipitation anomalies are associated with El Niño Southern Oscillation (ENSO) and La Niña events, where excessive rainfall is related to El Niño, whereas La Niña reduces rainfall in southern Brazil (Grimm et al., 1998, 2000).
Table I. Sediment description of the Rincão das Cabritas core from the São Francisco de Paula region, southern Brazil

\begin{tabular}{ll}
\hline Depth $(\mathrm{cm})$ & Sediment description \\
\hline $0-7$ & Weakly decomposed peat with Sphagnum spp. \\
$7-30$ & Decomposed peat with fine roots \\
$30-87$ & Dark brown decomposed peat rich in fine roots \\
$87-123$ & Black highly decomposed peat with many roots and \\
& plant remains \\
$123-224$ & Dark brown strongly decomposed peat with clay \\
$224-28 \mid$ & Light brown clay with little organic matter \\
\hline
\end{tabular}

\section{Methods}

The core has a length of $281 \mathrm{~cm}$ and was sampled with a Russian corer from the deepest part of the bog. Seventy-one volumetric subsamples of $0.25-1 \mathrm{~cm}^{3}$ were taken every $4 \mathrm{~cm}$ along the core for pollen and charcoal analysis. Each subsample was prepared applying hydrofluoric acid treatment and acetolysis (Faegri and Iversen, 1989). In order to calculate pollen and charcoal concentration, one tablet of Lycopodium clavatum marker was added to each sample (Stockmarr, 1971). Subsequently, the samples were mounted in glycerin gelatin and counted up to a minimum of 300 pollen grains each. The identification of the diverse pollen and spore types was simplified by the use of the reference collection of the Department of Palynology and Climate Dynamics, University of Göttingen together with morphological descriptions of Behling (1993) and Cancelli (2008). The acetolysed Lycopodium clavatum marker was distinguished from the naturally occurring L. clavatum spores on the basis of the dark coloration and of its wrinkled aspect. For calculations and plotting of pollen, spore and charcoal results, we used the programs TILIA and TILIAGRAPH (Grimm, 1991). Pollen and spores were calculated as percentages of the pollen sum, which included different taxa of grasses, herbs, shrubs and trees and excluded aquatic taxa and pteridophytes. All terrestrial and aquatic taxa were grouped into different ecological groups. Pollen taxa that could not be included in any other vegetation type or had a wider geographical distribution were included in 'Others'. The zonation of the pollen record is based on marked changes in the pollen assemblages and the cluster dendrogram calculated with CONISS (Grimm, 1987). The charcoal analysis is based on microscopic $(5-150 \mu \mathrm{m})$ charred particles which were counted on the pollen-slides.

Seven subsamples were sent for radiocarbon dating by Accelerator Mass Spectrometry (AMS) at the Institute of Physics of the Erlangen-Nürnberg University, Germany. An age-depth model was established using linear interpolation between calibrated ages, which was used to describe the pollen diagrams.

\section{Results}

\section{Lithology}

The $281 \mathrm{~cm}$ long sediment core from Rincão das Cabritas (RdC) consists of light brown clay in the lower core section (281-224 $\mathrm{cm})$. From 224 to $7 \mathrm{~cm}$ core depth, the sediment is composed of decomposed peat. The overlaying section $(7-0 \mathrm{~cm}$ depth) consists of weakly decomposed peat. A detailed description of the stratigraphic changes in the core is shown in Table 1 and Figure 4.

\section{Chronology}

The chronology for the core Rincão das Cabritas (RdC) was obtained from seven AMS radiocarbon dates (Table 2). The calibration of the radiocarbon dates was performed using the software CALIB 6.0 (Stuiver and Reimer, 1993) applying the data set of SHCal04 (McCormac et al., 2004) to the date of 
Table 2. Radiocarbon dates for the Rincão das Cabritas core

\begin{tabular}{|c|c|c|c|c|c|}
\hline Laboratory code & Sample depth $(\mathrm{cm})$ & Sample type & $\begin{array}{l}\text { Conventional age } \\
\left({ }^{14} \mathrm{C} \text { yr BP }\right)\end{array}$ & $\begin{array}{l}\text { Age range }^{\mathrm{a}} \\
\text { (cal.yr BP) }\end{array}$ & $\begin{array}{l}\text { Med. prob. } \\
\text { (cal.yr BP) }\end{array}$ \\
\hline Erl- 12100 & 45 & wood & $704 \pm 42$ & $558-670$ & 612 \\
\hline Erl-I5I20 & 85 & wood & $1786 \pm 38$ & $1534-1734$ & $|64|$ \\
\hline Erl-II 387 & 126 & peat & $2847 \pm 37$ & $2783-2995$ & 2892 \\
\hline Erl-1210I & 171 & peat & $5997 \pm 45$ & $6659-6894$ & 6769 \\
\hline Erl-I 2655 & 210 & peat & $10245 \pm 68$ & || 409-12 |49 & 1 I 877 \\
\hline Erl- 12102 & 228 & peat & $12578 \pm 66$ & $|4239-15| 70$ & 14806 \\
\hline Erl-I I 388 & 279 & wood & $13503 \pm 68$ & $16369-16902$ & 16679 \\
\hline
\end{tabular}

aRange at standard deviation of $2 \sigma, 95.4 \%$ probability.

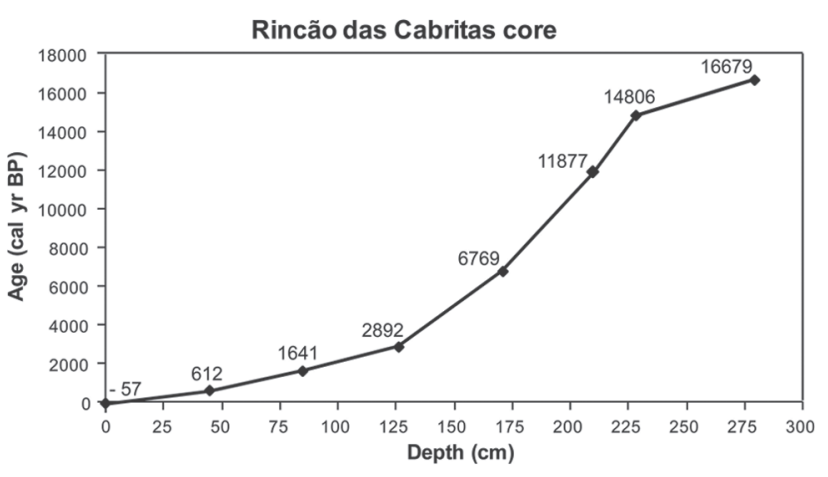

Figure 2. Depth-age curves for the Rincão das Cabritas core. All ages are in calibrated radiocarbon dates (cal. yr BP)

$10245{ }^{14} \mathrm{C}$ yr BP and of intcal09.14c (Reimer et al., 2009) for the two older radiocarbon dates. A median probability was adopted for each calibrated age range. The base of the core is extrapolated to be of an age of $16700 \mathrm{cal}$. BP, indicating that the sediment reaches back to the end of the full glacial period. The depth versus age relationship (Figure 2) suggests an irregular sediment accumulation through time. During the period between about 16700 and $14800 \mathrm{cal}$. BP, sedimentation rates are high (c. $0.272 \mathrm{~mm} / \mathrm{yr}$ ). Sedimentation rates are low (c. $0.061-0.116 \mathrm{~mm} /$ yr) from approximately 14800 until $3000 \mathrm{cal}$. BP. Since about 3000 cal. BP, sedimentation rates are increasing (c. 0.328-0.673 $\mathrm{mm} / \mathrm{yr})$.

\section{Description of the pollen diagram}

In total, 114 identified pollen and 23 different spore taxa were recorded in 71 sediment samples. Pollen types that could not be identified were classified by morphological characteristics and included in 'Unknowns'. Most frequent and important pollen and spore types are shown in the percentage pollen diagram (Figure 3). Figure 4 displays a summary percentage diagram of the grouped taxa into different vegetation types together with pollen and charcoal concentration.

Zone RdC-I (280-230 cm, 13520-12600 yr BP or I670014900 cal. BP, I 3 samples). This zone is dominated by high percentages (82-92\%) of Campos taxa, primarily Poaceae (44-67\%), Cyperaceae $(\leq 4 \%)$, Plantago $(\leq 11 \%)$, Apiaceae $(\leq 9 \%)$, Eryngium type $(\leq 10 \%)$ and Asteraceae $(\leq 19 \%)$. Pollen of forest taxa is less represented with values of up to $6 \%$ for the Araucaria forest and up to $2 \%$ for the Atlantic rainforest group. This zone contains very low pollen abundances of Myrsine, Myrtaceae, Mimosa scabrella type, Podocarpus, Ilex, Araucaria angustifolia, Clethra type, Weinmannia type, Celtis and Moraceae/Urticaceae (each $>3 \%$ ). The aquatic group is represented by pollen of Myriophyllum type, Echinodorus and Hydrocotyle type, which account for 0.3 $4 \%$. Pteridophyta, mostly spores of Isoëtes (up to $5 \%$ ), are well represented and vary between 2 and 9\%. Moss spores occur in very low proportions $(<0.7 \%)$. Pollen concentrations are low $(300$ $\times 10^{6}-800 \times 10^{6}$ grains $\left./ \mathrm{cm}^{3}\right)$ whereas concentrations of carbonized particles are high $\left(13000 \times 10^{9}-120000 \times 10^{9}\right.$ particles/ $\mathrm{cm} 3)$.

Zone RdC-II (230-186 cm, I 2600-7600 yr BP or 14900-8700 cal. BP, I I samples). This zone is characterized by high percentages of Campos taxa (88-91\%) and low percentages of Araucaria forest taxa $(2-4 \%)$ and Atlantic rainforest taxa (1-3\%). Pollen percentages of Poaceae, Cyperaceae and some Asteraceae taxa increase, whereas Plantago, Apiaceae and Eryngium type decrease. Pollen of Myriophyllum type has one maximum of $4 \%$ at the bottom of the zone, but decreases to $0 \%$ towards the top. The last pollen of Echinodorus was recorded at the end of this zone while Hydrocotyle type pollen is absent. The Tree ferns group occurs with low amounts $(\leq 1.3 \%)$. Pteridophyta spores remain at the same level (3-8\%) but proportions of Isoëtes decrease to $0 \%$. Mosses are represented by increasing values of Sphagnum (2-10\%) and Phaeoceros laevis (0.3-13\%). Concentrations of pollen $\left(400 \times 10^{6}-1500 \times 10^{6}\right.$ grains $\left./ \mathrm{cm}^{3}\right)$ and of microscopic charred particles $\left(170000 \times 10^{9}-480000 \times 10^{9}\right.$ particles $\left./ \mathrm{cm} 3\right)$ show higher values.

Zone RdC-III (I 86-1 26 cm, 7600-2900 yr BP or 8700-2950 cal. $B P, 15$ samples). This zone shows a slight decrease in Campos taxa from $86 \%$ to $60 \%$, mostly due to decreasing pollen frequencies of Poaceae and Plantago. The Araucaria forest group is represented by increasing values of Myrsine (1-8\%) and Myrtaceae (0.3-4\%), while pollen percentages of other Araucaria forest taxa continue to be low. Atlantic rainforest taxa also reach higher values, mostly due to increasing pollen percentages of Weinmannia type $(0-11 \%)$ and Alchornea $(0.3-3 \%)$. Melastomataceae pollen abundances increase compared with the previous zone. Proportions of Aquatic taxa $(\leq 0.3 \%)$ and Isoëtes spores $(\leq 0.3 \%)$ are very low. The Tree ferns and Pteridophyta groups show an increasing trend from $0 \%$ to $3 \%$ and from $2 \%$ to $11 \%$, respectively. Spores of Sphagnum increase markedly at the beginning (up to $36 \%$ ), but decline towards the top of the zone, while percentages of Phaeoceros laevis spores remain at relatively high proportions. Pollen concentrations are lower with values between $170 \times 10^{6}$ and 600 $\times 10^{6}$ grains $/ \mathrm{cm} 3$ whereas charcoal concentrations continue to be high $\left(130000 \times 10^{9}\right.$ and $340000 \times 10^{9}$ particles $\left./ \mathrm{cm} 3\right)$.

Zone RdC-IV (I26-62 cm, 2900-II60 yr BP or 2950-1050 cal. $B P, 16$ samples). This zone is marked by a strong decrease in Campos taxa from $19 \%$ to 3\%, reflected by a sharp decline of Poaceae with values between 2 and $9 \%$ and low pollen percentages of Asteraceae and other grassland taxa. Pollen of forest taxa increase 


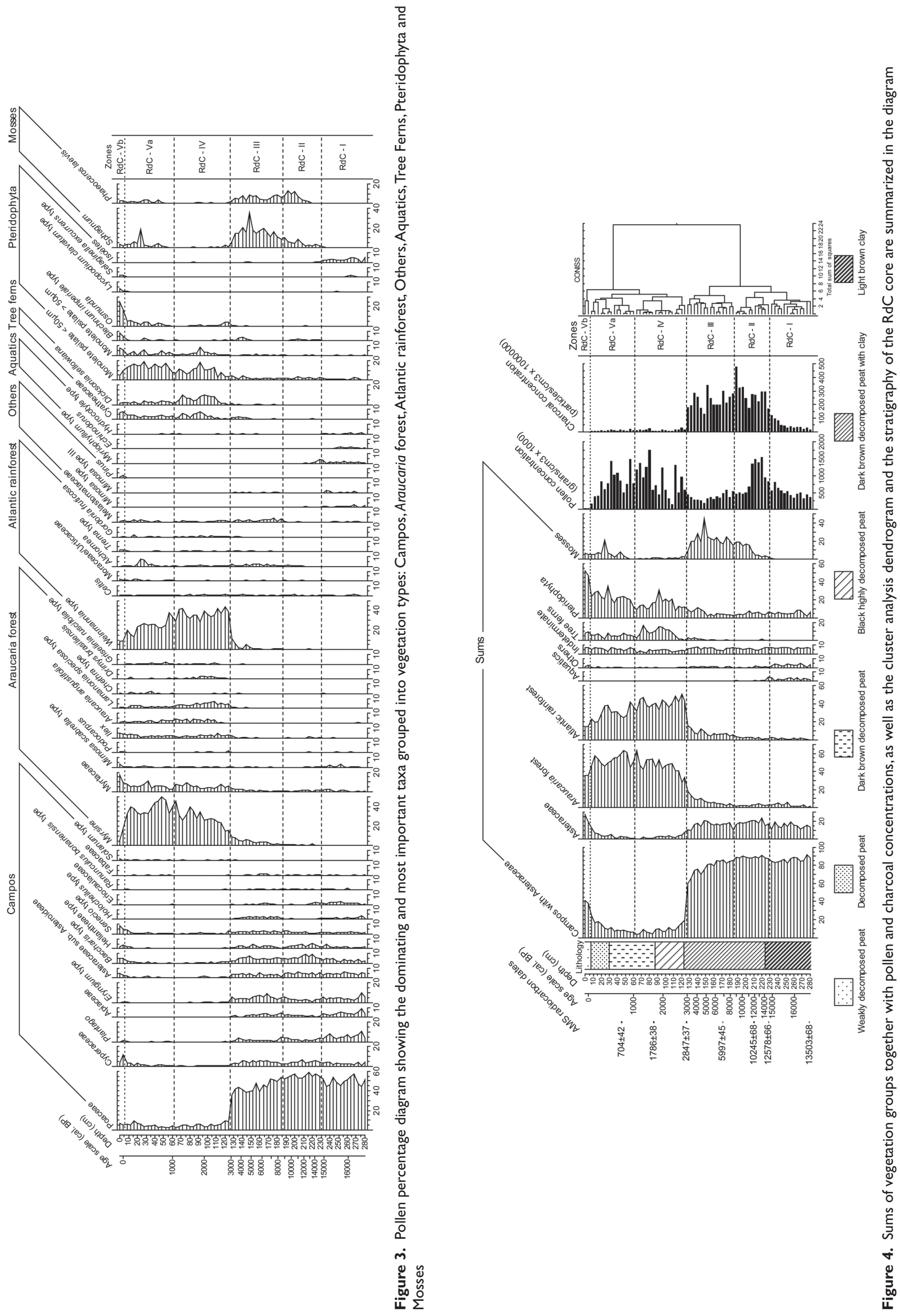


considerably, reaching proportions up to $63 \%$ for the Araucaria forest and up to $49 \%$ for the Atlantic rainforest group. Pollen percentages of the Araucaria forest group increase (Myrsine, Myrtaceae, Ilex, Araucaria angustifolia, Lamanonia speciosa type, Drimys brasiliensis and Griselinia ruscifolia type). Pollen frequencies of Weinmannia type increase highly up to $44 \%$ while percentages of Alchornea and Melastomataceae decrease in this zone. The Tree ferns group increases in this zone up to $16 \%$, because of higher proportions of Cyatheaceae and Dicksonia sellowiana spores. Abundances of Pteridophyta spores continue to increase (8-31\%), whereas the Moss group decreases markedly $(\leq 3 \%)$ due to low values of Sphagnum and Phaeoceros laevis spores. Values of pollen concentration are higher $\left(140 \times 10^{6}-1750 \times 10^{6}\right.$ grains/ cm3) whereas the ones of charcoal concentration are markedly lower $\left(4700 \times 10^{9}-29000 \times 10^{9}\right.$ particles $\left./ \mathrm{cm} 3\right)$.

Zone RdC-V (62-0 cm, II60 yr BP-present or 1050 cal. BPpresent, 16 samples). This zone is characterized by high percentages of Araucaria forest taxa (36-64\%) and decreasing values of Atlantic rainforest taxa (42-13\%). Campos taxa increase continuously from 13 to $42 \%$. Pollen concentrations are high $\left(1500 \times 10^{6}\right.$ grains $\left./ \mathrm{cm} 3\right)$ at the beginning of the zone and very low $\left(23 \times 10^{6}\right.$ grains $\left./ \mathrm{cm} 3\right)$ in the upper part. Values of charcoal concentration remain low $\left(370 \times 10^{9}-18000 \times 10^{9}\right.$ particles $\left./ \mathrm{cm} 3\right)$. This zone is divided into two subzones. Subzone RdC-Va (62-6 $\mathrm{cm}, 1160-45 \mathrm{yr}$ BP or 1050-30 cal. BP, 14 samples) shows a further increase in pollen percentages of Myrsine (up to 50\%) and Clethra type, while other Araucaria forest taxa decrease slightly or remain at the same proportions. The same can be observed in subzone $R d C-V b(6-0 \mathrm{~cm}, 45 \mathrm{yr} \mathrm{BP}-$ present or 30 cal. BP-present, 2 samples), except for pollen frequencies of Myrsine which decrease and for Myrtaceae and Mimosa scabrella type which increase towards the top. Pollen abundances of Weinmannia type decrease continuously until the top of the core (38-9\%). Alchornea pollen reaches higher values up to $7 \%$ at subzone RdC-Va, but decreases in the next subzone. Pinus pollen appears for the first time at the upper part of subzone $\mathrm{RdC}-\mathrm{Va}$ and is represented, together with Trema type, by higher percentages in the subsequent subzone. In subzone RdC-Va, pollen of Campos taxa are present with low percentages only, whereas pollen of Cyperaceae and some Asteraceae taxa increase in the upper part of this subzone and continue to increase in the following subzone. Tree fern taxa decrease compared with the previous zone, but spores of Cyatheaceae increase slightly in subzone RdC-IVb. The Pteridophyta group is represented by increasing values of Monolete psilate $<50 \mu \mathrm{m}$, Monolete psilate $>50 \mu \mathrm{m}$, Blechnum imperiale type and Osmunda spores in subzone RdC-Va. The increasing trend continues in the following subzone, including spores of Lycopodium clavatum type and Selaginella excurrens type, only Monolete psilate $<50 \mu \mathrm{m}$ decreases. The Moss group increases and is relatively well represented in both subzones with Sphagnum reaching values up to $19 \%$.

\section{Interpretation and discussion}

\section{Last glacial (I 3 520-I 2600 yr BP or I6 700-14900 cal. $B P$; Zone I)}

During the recorded full glacial and Lateglacial period, the landscape was dominated by grassland formed by forbs and graminoids, mostly Poaceae, Plantago, Apiaceae, Eryngium, different Asteraceae and other plants that are characteristic for open vegetation. Some Myrtaceae may represent shrubs growing in the grassland at this period. According to Schüler and Behling (2011a, b), Poaceae species of grasslands during glacial times on the southern Brazilian highland can probably be seen as a mixture of Pampa (found further south in the lowlands of southern South
America) and high-elevation grassland (Campos de Altitude) vegetation (found further north in the higher mountains of southern and southeastern Brazil). A few forest taxa and tree ferns were present in small populations probably on the lower slopes with sufficiently retained moisture or as gallery forest along rivers or streams at lower elevations. Among the Araucaria forest taxa were Mimosa scabrella, Podocarpus, Araucaria angustifolia and Clethra, whereas Weinmannia, Celtis and Moraceae/Urticaceae belong to Atlantic rainforest. The presence of Isoëtes, which is commonly found in seasonally wet to aquatic habitats and of aquatic taxa as Myriophyllum, Echinodorus and Hydrocotyle suggests local shallow water conditions in the studied basin during this period. Furthermore, the occurrence of some Cyperaceae and Eriocaulaceae confirms local water saturation.

The dominance of grassland reflects dry and cold climatic conditions in the region during the later part of the full glacial and Lateglacial. The rainfall of nowadays about $2500 \mathrm{~mm} / \mathrm{yr}$ in São Francisco de Paula region (Moreno, 1961; Nimer, 1989) must have been markedly reduced during Lateglacial times. However, sporadic strong rainfall may have provided the local prerequisites for shallow water in the basin. Environmental reconstructions by different authors have been consistent by suggesting that grassland dominated the highlands of Rio Grande do Sul state during glacial times under cold and relatively dry climate and that some Araucaria forest taxa were present only in refugia, such as in deep valleys or on coastal slopes with sufficient moisture (Behling et al., 2004; Leonhardt and Lorscheitter, 2010; Roth and Lorscheitter, 1993). Vegetation development and climate change on the highlands of southern Brazil shown by palynological studies performed on different sites are summarized in Table 3.

Pollen data from São Francisco de Paula (Leonhardt and Lorscheitter, 2010) point to the presence of a local shallow lake between 25000 and $16000 \mathrm{yr}$ BP, whereas data from Cambará do Sul (Behling et al., 2004) indicate a local permanent shallow lake before $26900 \mathrm{yr}$ BP and a non-permanent lake until $10120 \mathrm{yr}$ BP. Our results show that a local shallow lake existed before $12600 \mathrm{yr}$ $\mathrm{BP}$ which became a peat bog afterwards.

\section{Lateglacial to early Holocene (I 2600-7600 yr BP or I 4900-8700 cal. BP; Zone II)}

The São Francisco de Paula region continues to be characterized by a treeless landscape with Campos as the predominant vegetation community. A small number of forest taxa represented by Myrsine, Podocarpus, Ilex, Lamanonia speciosa, Clethra, Weinmannia, Celtis, Moraceae/Urticaceae and Alchornea indicate the existence of some trees in protected areas of drought. These can have been refugia with sufficient moisture at lower elevations in valleys or on the slopes. Some of the tree species such as Myrsine, Ilex, Lamanonia speciosa, Weinmannia, Moraceae/Urticaceae and Alchornea may reflect a first forest movement from the lower slopes to higher elevations of the Serra Geral, which can have been favored by warmer and wetter conditions after the Lateglacial period. The presence of some dispersed Atlantic rainforest taxa at the beginning of the Holocene at about $10000-8000 \mathrm{yr}$ BP along the coastal plain and valleys of the Serra Geral is documented by Lorscheitter (2003). More recently, Leal and Lorscheitter (2007) propose the spreading of Atlantic rainforest from east to west since $8800 \mathrm{yr}$ BP based on a sediment profile from the lower northeast slope of the Serra Geral. After c. $12600 \mathrm{yr}$ BP, the continuous bog formation began with the local occupation of Sphagnum as a peat moss and Blechnum imperiale as a fern growing on the site. The presence of Sphagnum combined with the almost disappearance of aquatic taxa and Isoëtes point to periods of pronounced drought, but sufficient local humidity. The increase of Poaceae together with the decrease of Plantago, Apiaceae, Eryngium, Eriocaulaceae and possible absence of Araucaria 


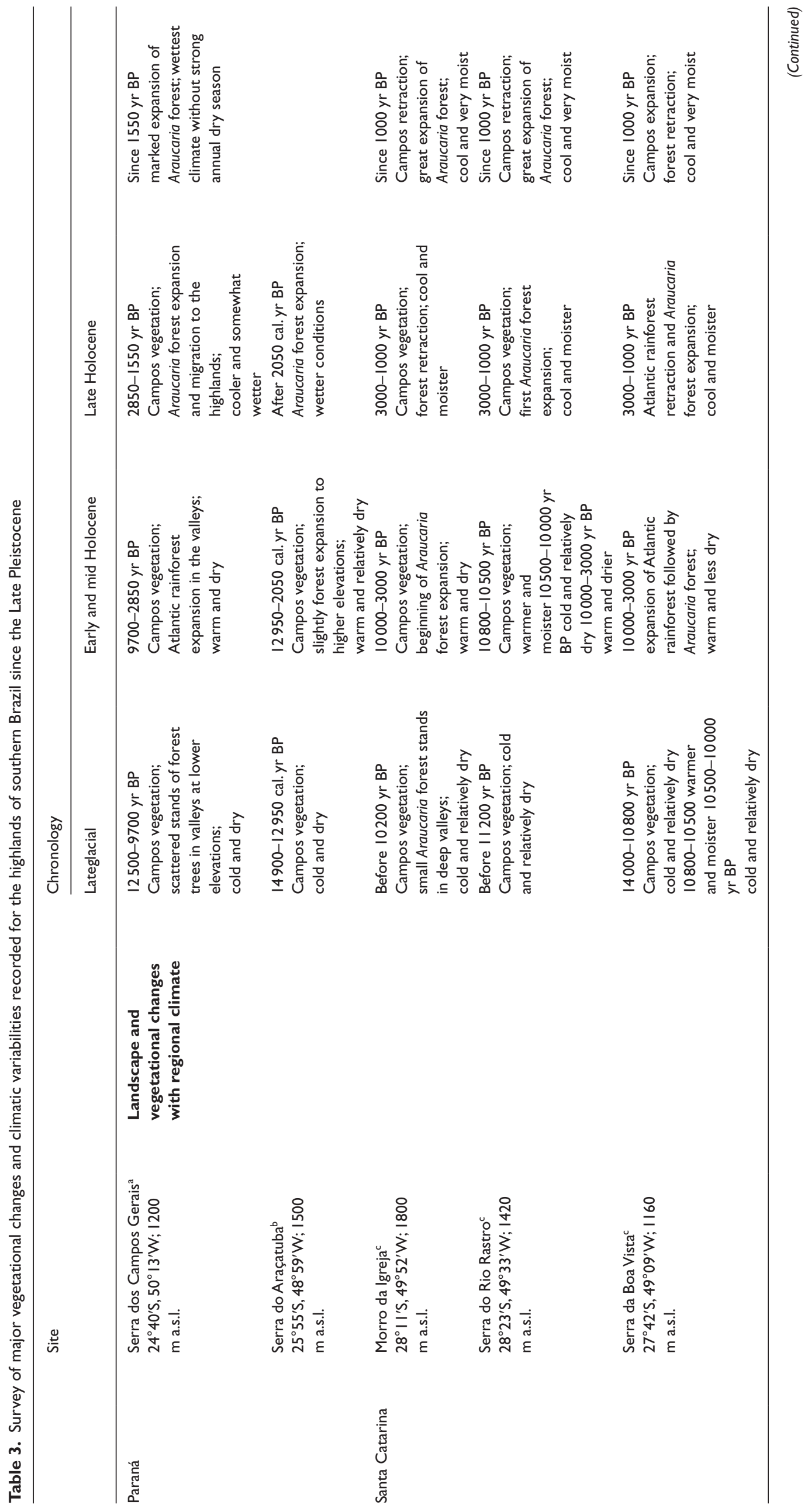




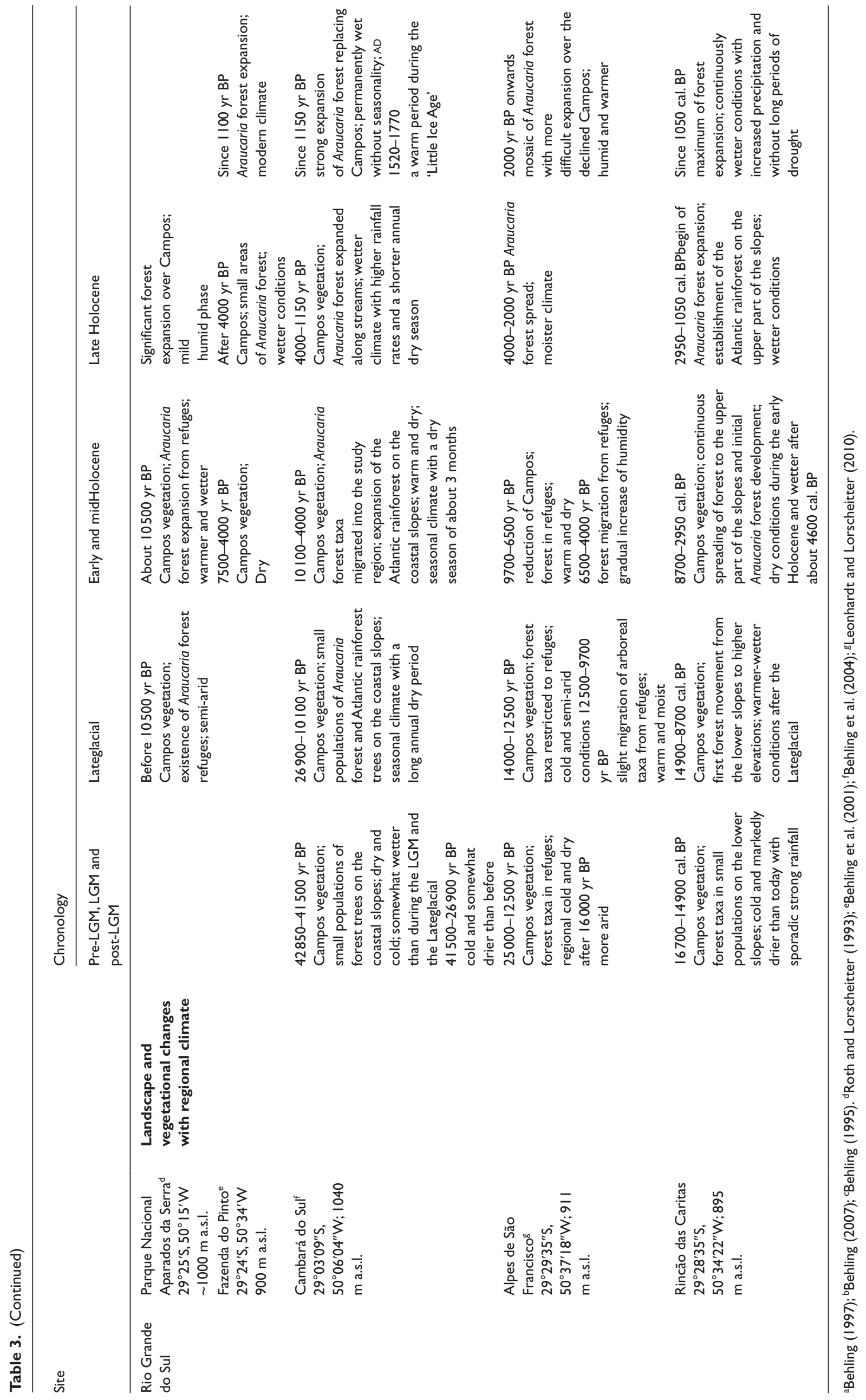


angustifolia (no pollen grains) indicate for longer dry periods. According to Hueck (1966), Araucaria angustifolia can neither endure annual precipitation levels lower than $1000 \mathrm{~mm}$ nor long dry seasons.

Extensive Campos vegetation points to regionally dry climatic conditions extending from the Lateglacial to the early Holocene. The results of research by other authors have been consistent with respect to dry climatic conditions in the region during this period. According to Behling et al. (2004), climate was dry with annual long dry period from 10120 to $3950 \mathrm{yr}$ BP and markedly drier than today from 7500 to $4000 \mathrm{yr}$ BP (Behling et al., 2001). However, for Leonhardt and Lorscheitter (2010), the climate was warm and dry between 9700 and $6500 \mathrm{yr}$ BP. On the other hand, Roth and Lorscheitter (1993) propose a warmer and wetter climate at the beginning of the Holocene at about $11000 \mathrm{yr}$ BP and according to Leonhardt and Lorscheitter (2010), it was warm and moist from 11000 to $9700 \mathrm{yr}$ BP. However, dry climatic conditions are also confirmed by other studies, which show the dominance of Campos vegetation on the highlands of Santa Catarina (Behling, 1995) and Paraná state (Behling, 1997).

\section{Early to mid Holocene (7600-2900 yr BP or 8700-2950 cal. BP; Zone III)}

Campos vegetation composed mostly of Poaceae and Asteraceae continues to prevail in the region. Forest indicators as the pioneer taxa Myrsine, Lamanonia speciosa and Alchornea (Backes and Irgang, 2002, 2004) as well as Weinmannia, Myrtaceae and Cyatheaceae point to a continuous spreading of forest from the lower to the upper part of the slopes and an initial Araucaria forest development. At this period, the peat bog became completely developed. It was mostly dominated by Sphagnum but consisted also of other bog vegetation taxa, such as some Cyperaceae and Eriocaulaceae as well as Blechnum imperiale.

Campos vegetation remained the predominant ecosystem on the highlands under dry climatic conditions during the early Holocene. However, a moderate and wetter climate since the mid Holocene allowed for gradual forest spreading from the lower regions of the Serra Geral upwards to higher elevations. The increasing frequency of moist forest taxa, such as Myrsine, Myrtaceae, Lamanonia speciosa, Weinmannia and Cyatheaceae as well as of bog taxa such as Blechnum imperiale, Osmunda and Sphagnum indicate for a slightly wetter climate after about $4250 \mathrm{yr}$ BP. Increased moisture levels after 4000 yr BP correlate with an increasing humidity reported from Cambará do Sul (Behling et al., 2004) with a first Araucaria forest expansion. Similar conditions with small areas of Araucaria forest are shown for the São Francisco de Paula region (Behling et al., 2001). For the same region, Leonhardt and Lorscheitter (2010) suggest a gradual increase of humidity between 6500 and $4000 \mathrm{yr}$ BP and an Araucaria forest expansion under moister climatic conditions between 4000 and $2000 \mathrm{yr}$ BP. Additionally, a wet climate since $4000 \mathrm{yr}$ BP has been recorded for the southern Brazilian coastal lowland (Cordeiro and Lorscheitter, 1994). In respect of climatic improvement towards warmer-wetter conditions in the Holocene, Roth and Lorscheitter (1993) show a significant forest expansion over Campos, which is related to a mild and humid phase.

\section{Late Holocene (2900-I I 60 yr BP or 2950-1050 cal. BP; Zone IV)}

The Araucaria forest expansion in the region began at approximately $2900 \mathrm{yr}$ BP. It is reflected by an increase in arboreal pollen taxa frequencies, such as Myrsine, Myrtaceae, Ilex, Araucaria angustifolia, Lamanonia speciosa, Drimys brasiliensis and Griselinia ruscifolia. At the same time, the establishment of the Atlantic rainforest on the upper part of the slopes is suggested by the presence of Weinmannia together with other tree taxa and tree ferns belonging to this ecosystem. It is worth noting that Weinmannia increased exactly simultaneously with the abrupt decrease of Poaceae. This does not account for the almost disappearance of Campos vegetation or a replacement of this vegetation community by forest, but most probably reflects the presence of Weinmannia pollen in the sediment. Therefore, a high pollen production of Weinmannia does not represent its dominance in the landscape but is more owed to its local presence. Despite a higher sediment deposition, an expected low pollen concentration since about 3000 cal. BP was not encountered in our results (Figure 4). It is possible that a greater pollen production of forest compared with Campos taxa has led to higher pollen concentration rates. A vegetation change from a grassland landscape to a forested ecosystem since 3000 cal. BP is shown in the pollen diagrams (Figures 3 and 4). The shift of the forest around the bog supports the idea that higher pollen concentrations are caused by a higher pollen production of forest taxa. It is unclear why Sphagnum has declined during this period and the reasons for the desiccation of the peat bog. It may be possible that the peat bog was reduced and substituted by the surrounding vegetation formed by Araucaria forest and some Atlantic rainforest taxa which were temporarily more widespread in the Araucaria forest since the last 3000 years.

Forest covered the study site during this period, thus pointing to a climatic amelioration to wetter conditions. The Araucaria forest development began at about 3950 yr BP in Cambará do Sul, but its expansion and the replacement of Campos took place much later, after $1140 \mathrm{yr}$ BP (Behling et al., 2004). This result differs from ours that demonstrate a continuous expansion of Araucaria forest in São Francisco de Paula region since the mid Holocene, after c. $2900 \mathrm{yr}$ BP. Evidence for a moister mid to late Holocene, which lead to the initial expansion of Araucaria forest, is also given by other studies that have been carried out on the highlands of Santa Catarina (Behling, 1995) and Paraná state (Behling, 1997, 2007), situated further north.

\section{Last millennium (I 160 yr BP-present or 1050 cal. BP-present; Zone V)}

The replacement of Campos by forest ecosystems continued until the last millennium, although the Atlantic rainforest seems to have declined in the São Francisco de Paula region. This reduction is primarily indicated by the decrease of Weinmannia and the tree fern family of Cyatheaceae. The reduction of the Atlantic rainforest reflects a vegetational change caused by the expansion of the Araucaria forest in the region. The latter became the main vegetation type on the highlands forming Campos-forest mosaics. Local Araucaria forest expanded increasingly since the last 1000 years, thereby leading to a vegetational change also on the upper part of the Serra Geral close to its slopes that became a transition zone between Atlantic rainforest and Araucaria forest since then. During the last millennium, the bog regenerated and was covered by Sphagnum and other plants characteristic for bog communities, such as Blechnum imperiale, Osmunda and Phaeoceros laevis. However, the peat bog has been influenced by human activities over the last decades. This is reflected by a continue increase of Blechnum imperiale, Osmunda, Lycopodium clavatum, Selaginella excurrens and some Cyperaceae that suggest a bog growth within the forest because of opening of the forest since $c$. AD 1890. A bog expansion could also have been promoted by the accumulation of water in the basin, which then allowed the emergence of bog taxa adapted to high moisture levels.

Climatic conditions continued to become wetter during the last 1000 years with an increased precipitation that coincides with the maximum forest expansion. This is consistent with Behling et al. (2004) who documented the wettest period without a marked annual dry season since $1140 \mathrm{yr}$ BP and noted a replacement of 
Campos by Araucaria forest in Cambará do Sul. Furthermore, Behling et al. (2001) recorded a forest expansion since $1060 \mathrm{yr}$ BP. However, they suggest an expansion of Araucaria angustifolia trees only since 850 yr BP in the São Francisco de Paula region under climatic conditions similar to the modern climate. These interpretations, proposing a much later forest expansion than indicated from the results presented here, could be explained by the extensive use of Campos areas as a natural pasture with distant patches of disturbed Araucaria forest at the study site. A study on the dynamics of a small Araucaria forest island in the region showed its development and expansion associated to fire frequency after $490 \mathrm{yr}$ BP (Jeske-Pieruschka et al., 2010). A pronounced Araucaria forest expansion is reported since about 1000 yr BP in Santa Catarina state (Behling, 1995) and since about 1400 yr BP in Paraná state (Behling, 1997).

The first occurrence of Pinus at c. AD 1890 points to an ecosystem disturbance by the introduction of these exotic trees. The reduced arboreal taxa reflect continuing but decreasing disturbance with the expansion of shrubs. This is evidenced by the increase of Asteraceae since the end of the nineteenth century. Also, disturbance indicators such as Mimosa scabrella and Trema increased over the past 60 years. Disturbance of the native vegetation, resulting in a forest opening, can be related to human activities, such as the introduction of cattle by Jesuits probably during the early eighteenth century (Pillar, 2003) and the exploitation of Araucaria angustifolia by European settlers since the nineteenth century (Reitz et al., 1988).

\section{Climate as the main limiting factor for forest expansion}

The interpretations regarding the first development and expansion of the Araucaria forest over Brazilian southernmost highlands after 4000 yr BP under wetter conditions (Behling et al., 2001, 2004; Leonhardt and Lorscheitter, 2010) are consistent with our results (see Table 3). Palaeoenvironmental records confirmed a marked Araucaria forest expansion in the São Francisco de Paula region since about 1000 years, which can be correlated with an increased precipitation and the absence of longer dry periods (Behling et al., 2001, 2004). Hence, the fact that a pronounced expansion of Araucaria forest covering Campos on the highlands of Rio Grande do Sul was very late, although small forest populations were already present there, can be explained with higher precipitation rates and a lack of drought since the last 1000 years. Therefore, the evidence points to climate, i.e. higher rainfall distributed throughout the year, as the most important factor controlling the Araucaria forest expansion on the highlands of southern Brazil. For Leonhardt and Lorscheitter (2010), a humid but warmer climate was responsible for limiting the expansion of forest since $2000 \mathrm{yr}$ BP because it affected the reproductive capacity of Araucaria forest taxa. We do not consider, however, that the climate has become warm to such an extent that it served as a potentially limiting factor for forest expansion. Our results rather show an increase of taxa belonging to this ecosystem since at least $2600 \mathrm{yr}$ BP, including Araucaria angustifolia itself. However, we have to consider this possibility, as we used percentage data for reconstructing environmental history instead of concentration data as did Leonhard and Lorscheitter. Similar observations have been made by Silva et al. (2009). They suggest that Araucaria angustifolia can have growth limitations under lower precipitation and higher temperature levels. Hence, the evidence shows that future climate changes will strongly influence Araucaria forest ecosystems.

Regional environmental differences such as soil depth, edaphic properties, local drainage and topography have also to be considered as possible limiting factors of forest expansion in different times. According to Dümig et al. (2008), development and permanence of Andosols is favored by grassland vegetation and the loss of its andic properties caused by forest expansion due to crystallization of $\mathrm{Al}$ and $\mathrm{Fe}$ oxides. The authors show also that variations of soil properties of the Brazilian southernmost highlands occur in different vegetation types. However, according to them these do not control the expansion of Araucaria forest into grassland.

Another explanation for forest expansion taking place in different times could be anthropogenic activity, such as induced fires and forest exploitation. It is known from different studies that Campos areas have been subjected to fires in order to manage pastures for cattle farming (e.g. Behling and Pillar, 2007; Nabinger et al., 2000; Overbeck et al., 2005). More recently, Jeske-Pieruschka et al. (2010) demonstrated that Araucaria forest dynamics are strongly influenced by fire frequencies. We do not think, however, that these human interferences served as a substantially important cause of limiting Araucaria forest expansion but that they can rather be seen as a mechanism preventing forest expansion and controlling its stability.

\section{Fire history}

Results of the charcoal record show a rising trend of microcharcoal fragments at the end of the Lateglacial period. Higher concentrations of charred particles from the end of the late glacial (12650 yr BP) until the mid Holocene (3000 yr BP) suggest that fire activity was very common in the region. Fires of anthropogenic origin at the beginning of the Holocene in Paraná state (Behling, 1997) and after $7400 \mathrm{yr}$ BP in Rio Grande do Sul state (Behling et al., 2004), suggest an early human occupation of the southern Brazil highlands at different time periods. It may be possible that Amerindians have caused these fires at the transition of the Pleistocene to Holocene in the studied region. According to Prous and Fogaça (1999), the Umbu and Humaitá tradition occupied the southern Brazil at c. 8000 yr BP. On the other hand, because of the small size of the sedimentary charcoal particles (mostly $<50 \mu \mathrm{m}$ ), wind transportation from distant and overregional fire events cannot be excluded.

\section{Conclusions}

New palaeoecological interpretations for the São Francisco de Paula region are presented in this work based on the results of the $\mathrm{RdC}$ pollen and charcoal record. The investigated core, spanning the last $13520 \mathrm{yr}$ BP $(16700 \mathrm{cal}$. BP), provides specific information about the origin and history of the mosaic of grassland and Araucaria forest and its expansion during late Quaternary in the São Francisco de Paula region. During the recorded glacial period, the landscape was completely covered by grassland under cold and dry climatic conditions. Some forest taxa and tree ferns were only present in refugia on coastal slopes or as part of the gallery forest along rivers or streams with sufficiently retained humidity. The existence of a local shallow lake before $12600 \mathrm{yr}$ BP (14800 cal. BP), as well as similar interpretations of other researches in the same region, lead to the conclusion that a dry and cold climate with sporadic strong rainfall prevailed in the region throughout this period. The lake began to fill up after $c .12600 \mathrm{yr}$ BP (14800 cal. BP) and became a fully developed peat bog afterwards. The São Francisco de Paula region then continued to be characterized by a treeless landscape with Campos as the predominant vegetation community from the Late Pleistocene to the mid Holocene, thus pointing to dry climatic conditions. Over the last 4250 yr BP (4600 cal. BP), a wetter climate allowed the initial Araucaria forest development and a continued spreading of Atlantic rainforest from the lower to the upper parts of the slopes. The development of Araucaria forest began after 3100 yr BP (3200 cal. BP). 
However, its expansion started only about 2900 yr BP (2950 cal. BP). Climate became increasingly wetter since 1160 yr BP (1050 cal. BP), resulting in continuously forest expansion over Campos ecosystems. Araucaria forest spread progressively since the last 1000 years, thereby suppressing the Atlantic rainforest along the upper slopes and forming Campos-forest mosaics on the highlands. Climate seems to be the most important factor limiting Araucaria forest expansion on the highlands of southern Brazil. The disturbance of the native vegetation, resulting in forest opening, can be related to human practices since the end of the nineteenth century. Higher concentrations of microcharred particles from the Late Pleistocene to the mid Holocene point to frequent fires in the region during this time, thus probably indicating human occupation on the southern Brazil highlands.

\section{Acknowledgements}

Our thanks go to the owner of Rincão das Cabritas, Victor Umann, for permitting us to conduct fieldwork in his property. We would like to thank our field collaborators, especially Renato Backes Macedo and Rodrigo Rodrigues Cancelli for assistance with coring. We thank Dr Gerald Islebe for the review of the manuscript, and Dr Sonia Fontana for providing constructive comments on the manuscript. Thanks are also due to Nele Jantz for reading the English text.

\section{Funding}

The Deutsche Forschungsgemeinschaft (DFG) funded this research (BE 2116/9-1). The Inter American Institute for Global Change Research (IAI) is gratefully acknowledged for financial support for radiocarbon dating and part of the fieldwork.

\section{References}

Backes P and Irgang B (2002) Árvores do Sul: Guia de Identificação \& Interesse Ecológico. Porto Alegre: Instituto Souza Cruz.

Backes P and Irgang B (2004) Mata Atlântica: as árvores e a paisagem. Porto Alegre: Paisagem do Sul.

Behling H (1993) Untersuchungen zur spätpleistozänen und holozänen Vegetations- und Klimageschichte der tropischen Küstenwälder und der Araukarienwälder in Santa Catarina (Südbrasilien). Berlin, Stuttgart: J Cramer.

Behling H (1995) Investigations into the Late Pleistocene and Holocene history of vegetation and climate in Santa Catarina (S Brazil). Vegetation History and Archaeobotany 4: 127-152.

Behling H (1997) Late Quaternary vegetation, climate and fire history of the Araucaria forest and campos region from Serra Campos Gerais, Paraná State (South Brazil). Review of Palaeobotany and Palynology 97: 109-121.

Behling H (1998) Late Quaternary vegetational and climatic changes in Brazil. Review of Palaeobotany and Palynology 99: 143-156.

Behling H (2002) South and southeast Brazilian grasslands during Late Quaternary times: A synthesis. Palaeogeography, Palaeoclimatology, Palaeoecology 117: 19-27.

Behling H (2007) Late Quaternary vegetation, fire and climate dynamics of Serra do Araçatuba in the Atlantic coastal mountains of Paraná State, southern Brazil. Vegetation History and Archaeobotany 16: 77-85.

Behling H and Pillar VD (2007) Late Quaternary vegetation, biodiversity and fire dynamics on the southern Brazilian highland and their implication for conservation and management of modern Araucaria forest and grassland ecosystems. Philosophical Transactions of the Royal Society B 362: 243-251.

Behling H, Bauermann SG and Neves PCP (2001) Holocene environmental changes in the São Francisco de Paula region, southern Brazil. Journal of South American Earth Sciences 14: 631-639.

Behling H, Pillar VD, Orlóci L and Bauermann SG (2004) Late Quaternary Araucaria forest, grassland (Campos), fire and climate dynamics, studied by high-resolution pollen, charcoal and multivariate analysis of the Cambará do Sul core in southern Brazil. Palaeogeography, Palaeoclimatology, Palaeoecology 203: 277-297.

Boldrini II (2009) A flora dos Campos do Rio Grande do Sul. In: Pillar V, Müller SC, Souza Castilhos de ZM and Jacques AVÁ (eds) Campos Sulinos
- conservação e uso sustentável da biodiversidade. Brasilia: Ministério do Meio Ambiente, 63-77.

Cancelli RR (2008) Palinologia de Asteraceae: morfologia polínica e suas implicações nos registros do Quaternário do Rio Grande do Sul. MSc Dissertation, Porto Alegre: Universidade Federal do Rio Grande do Sul, Instituto de Geociências.

Cordeiro SH and Lorscheitter ML (1994) Palynology of Lagoa dos Patos sediments, Rio Grande do Sul, Brazil. Journal of Paleolimnology 10: 35-42.

Dümig A, Schad P, Kohok M, Beyerlein P, Schwimmer W and Kögel-Knabner I (2008) A mosaic of nonallophanic Andosols, Umbrisols and Cambisols on rhyodacite in the southern Brazilian highlands. Geoderma 145: 158-173.

Faegri K and Iversen J (1989) Textbook of Pollen Analysis. Chichester: Wiley.

Grimm EC (1987) CONISS: A Fortran 77 program for stratigraphically constrained cluster analysis by the method of the incremental sum of squares. Computers and Geosciences 13: 13-35.

Grimm E (1991) Tilia Software. Illinois State Museum.

Grimm AM, Barros VR and Doyle ME (2000) Climate variability in Southern America associated with El Niño and La Niña events. Journal of Climate 13: 35-58.

Grimm AM, Ferraz SET and Gomes J (1998) Precipitation anomalies in southern Brazil associated with El Niño and La Niña events. Journal of Climate 11: $2863-2880$

Hueck K (1953) Distribuição e habitat natural do Pinheiro do paraná (Araucaria angustifolia). Boletim da Faculdade de Filosofia e Ciências da Universidade de São Paulo - Botânica 10: 1-24.

Hueck K (1966) Die Wälder Südamerikas. Stuttgart: Fischer.

Instituto Brasileiro de Geografia e Estatística (IBGE) (1986) Projeto Radambrasil. Levantamento de Recursos Naturais, Vol. 33. Folha SH.22 Porto Alegre e Parte das Folhas SH.21 Uruguaiana e SI.22 Lagoa Mirim. Ministério das Minas e Energia, Secretaria-Geral, Rio de Janeiro, Brazil.

Instituto Brasileiro de Geografia e Estatística (IBGE) (2004) Mapa da vegetação do Brasil e Mapa de Biomas do Brasil. http://www.ibge.gov.br

Jeske-Pieruschka V (2011) Studies of vegetation, fire and climate dynamics during the late Quaternary as contribution towards conservation and management of the biodiversity hotspot 'Mata Atlântica' in southern Brazil. Ph.D. Thesis, Georg-August-Universität Göttingen, Institut für Pflanzenwissenschaften.

Jeske-Pieruschka V, Fidelis A, Bergamin RS, Vélez E and Behling H (2010) Araucaria forest dynamics in relation to fire frequency in southern Brazil based on fossil and modern pollen data. Review of Palaeobotany and Palynology 160: 53-65.

Klein RM (1960) O aspecto dinâmico do pinheiro brasileiro. Sellowia 12: $17-44$.

Klein RM (1975) Southern Brazilian phytogeographic features and the probable influence of upper Quaternary climatic changes in the floristic distribution. Boletim Paranaense de Geociencias 33: 67-88.

Leal MG and Lorscheitter ML (2007) Plant succession in a forest on the Lower Northeast Slope of Serra Geral, Rio Grande do Sul, and Holocene palaeoenvironments, Southern Brazil. Acta Botanica Brasilica 21: $1-10$.

Leonhardt A and Lorscheitter ML (2010) The last 25,000 years in the Eastern Plateau of Southern Brazil according to Alpes de São Francisco record. Journal of South American Earth Sciences 29: 454-463.

Lindman CAM (1906) A vegetação no Rio Grande do Sul. São Paulo/Belo Horizonte: EDUSP/Itatiaia.

Lorscheitter ML (2003) Contribution to the Holocene history of Atlantic rain forest in the Rio Grande do Sul state, southern Brazil. Revista del Museo Argentino de Ciencias Naturales 5: 261-271.

McCormac FG, Hogg AG, Blackwell PG, Buck CE, Higham TFG and Reimer PJ (2004) SHCAL04 Southern Hemisphere calibration, 0-11.0 cal kyr BP. Radiocarbon 46: 1087-1092.

Moreno JA (1961) Clima do Rio Grande do Sul. Porto Alegre: Secretaria da Agricultura.

Myers N, Mittermeier RA, Mittermeier CG, da Fonseca GAB and Kent J (2000) Biodiversity hotspots for conservation priorities. Nature 403: 853-858.

Nabinger C, Moraes A and Maraschin GE (2000) Campos in Southern Brazil. In: Lemaire G, Hodgson J, Moraes A, Nabinger C and Carvalho PCF (eds) Grassland Ecophysiology and Grazing Ecology. Wallingford: CABI Publishing, 335-376.

Nimer E (1989) Climatologia do Brasil. Rio de Janeiro: Fundação Instituto Brasileiro de Geografia e Estatística.

Overbeck GE, Müller SC, Pillar VD and Pfadenhauer J (2005) Fine-scale post-fire dynamics in southern Brazilian subtropical grassland. Journal of Vegetation Science 16: 655-664. 
Pillar VD (2003) Dinâmica da expansão florestal em mosaicos de floresta e campos no sul do Brasil. In: Claudino-Sales V (Org.) Ecossistemas Brasileiros: Manejo e Conservação. Fortaleza: Expressão Gráfica e Editora.

Prous A and Fogaça E (1999) Archaeology of the Pleistocene-Holocene boundary in Brazil. Quaternary International 53/54: 21-41.

Rambo B (1951) A Imigração da Selva Higrófila no Rio Grande do Sul. Sellowia 3: 55-91.

Rambo B (1956) A Flora Fanerogâmica dos Aparados Riograndenses. Sellowia 7: 235-298.

Reimer PJ, Baillie MGL, Bard E, Bayliss A, Beck JW, Bertrand C et al. (2009) Intcal09.14c. Radiocarbon 51: 1111-1150.

Reitz R, Klein RM and Reis A (1988) Projeto Madeira do Rio Grande do Sul. Porto Alegre: SUDESUL-HBR.

Roth L and Lorscheitter ML (1993) Palynology of a bog in Parque Nacional de Aparados da Serra, East Plateau of Rio Grande do Sul, Brazil. Quaternary of South America and Antarctic Peninsula 8: 39-69.
Schüler L and Behling H (2011a) Poaceae pollen grain size as a tool to distinguish past grasslands in South America - A new methodological approach. Vegetation History and Archaeobotany 20: 83-96.

Schüler L and Behling H (2011b) Characteristics of Poaceae pollen as a tool to assess palaeoecological grassland dynamics in South America. Vegetation History and Archaeobotany 20: 97-108.

Silva LCR, Anand M, Oliveira JM and Pillar VD (2009) Past century changes in Araucaria angustifolia (Bertol.) Kuntze water use efficiency and growth in forest and grassland ecosystems of southern Brazil: Implications for forest expansion. Global Change Biology 15: 2387-2396.

Stockmarr J (1971) Tablets with spores used in absolute pollen analysis. Pollen et Spores 13: 615-621.

Stuiver M and Reimer PJ (1993) Extended ${ }^{14} \mathrm{C}$ data base and revised CALIB $3.0{ }^{14} \mathrm{C}$ age calibration program. Radiocarbon 35: 215-230.

Tabarelli M, Pinto LP, Silva JMC, Hirota M and Bedê L (2005) Challenges and opportunities for biodiversity conservation in the Brazilian Atlantic forest. Conservation Biology 19: 695-700. 